\title{
Obituary
}

\section{John D. Turner, 1938-2019}

Cotner Professor of Religious Studies and Charles J. Mach Professor of Classics and History at the University of Nebraska-Lincoln

John D. Turner, one of the world's leading authorities on Gnosticism (especially the thirteen Coptic codices discovered in the desert in Egypt in 1945 near Nag Hammadi), died at his home in Lincoln, NE, after a brief battle with cancer on October 26, 2019. He was born on July 15, 1938, to Warren O. and Dorothy (Holdsworth) Turner in Glen Ridge, New Jersey. After the early death of his mother, he left home to be educated at Trinity Pawling Preparatory School, where he was a member of the football and track teams, graduating in 1956. He then attended Dartmouth College, majoring in philosophy and mathematics (1960), followed by a Bachelor of Divinity and Master of Theology at Union Theological Seminary in Richmond, Virginia (1965), but decided against New Testament Studies, instead obtaining a doctorate in Religion at Duke University (1970), a major turning point in his life.

Together with his supervisor, Orville Wintermute, and later James Robinson at Claremont Graduate School in California, both of whom had managed to get photographs of the Nag Hammadi papyrus library in Cairo, John helped to decode the damaged and almost indecipherable fragments of the Nag Hammadi codices. The group went on to publish from 1973-1977 a complete twelve volume photographic facsimile edition, reflecting as much as possible the fragments' original appearance at the time of their discovery. He produced a principal edition of The Book of Thomas the Contender from Codex II (Atlanta: SBL Press, 1975) and translated some of the most important Nag Hammadi texts into English, revolutionizing our understanding of this early period (Nag Hammadi Codices XI, XII and XIII, ed. C.W. Hedrick, Brill 1990; reprinted in The Coptic Gnostic Library. A Complete Edition of the Nag Hammadi Codices. Vol. 5, ed. James M. Robinson, Leiden, Boston, Köln: Brill, 2000). Over the course of his 
subsequent career, he became part of a French team, international but centered at Laval University in Quebec, that produced the definitive editions of these major Gnostic texts (known around the world as the Bibliothèque Copte de Nag Hammadi - notably in John's case, the works Zostrien and Marsanès in 200o; L'Allogène in 2004); among many other honors, he was invited to lecture in English at the foremost institution in Paris, France, the College de France; and his book Sethian Gnosticism and the Platonic Tradition (Bibliothèque copte de Nag Hammadi, québec: Presses de l'Université Laval; Louvain-Paris: Éditions Peeters, 2001) has come to define the multi-dimensional phenomenon of Classical or Sethian Gnosticism and to chart definitively its major role in the Platonic Tradition.

Beyond so many other qualities, John was a teacher and an administrator behind the scenes (he served as assistant Dean at Claremont, 1970-1971), who looked after and loved his students. At the University of Montana (1971-1975) before he came to Nebraska, he nurtured such talents as the Distinguished Harvard Professor and scholar of Gnosticism, Karen King, who wrote the following to him during his final weeks: "I remember you setting mimeographed translations of some of the Nag Hammadi texts in front of a class of bewildered students at U. of M. in the early 1970s. How they could be so compelling when it seemed nearly impossible to understand a thing they said still mystifies me. But you offered this whole new world to a bunch of small town Montana kids-now that was something."

At the University of Nebraska in Lincoln he founded the Program of Religious Studies - with no funding and no department status, started offering interdisciplinary courses in Comparative Religion and Christianity and Ways of Western Religion with professors of Physics, Music, Sociology of Religion, etc. to build up a program of as many as 800 students - until under a good anthropologist Dean, a department of History, then Classics was formed and, finally, a Department of Classics and Religious Studies. He won the Parents' Award for Outstanding Service to Students in three years and, together with his Cotner Chair, was named the Charles J. Mach University Professor of Classics and History in 2003.

In this his final position, he mentored students from all over the world and loved the brilliance of young people. He took Zeke Mazur under his wing at the University of Chicago - and helped to publish his works before Zeke's untimely death two years ago. Tuomas Rasimus, Dylan Burns, Lance Jenott-he marveled at their talent and regarded them as his sons. He was especially proud of the Nordic Nag Hammadi group, of his friendship with Einar Thomassen, Jean-Daniel Dubois, Christian Bull, and others. The Coptic Camp that he held 
every year-thanks to the support of his wife, Elizabeth Sterns-brought young people to their home from many corners of the world.

Over the past eighteen years, I have had the privilege of working with him: together we wrote six books and many articles; in collaboration with the many younger scholars he had mentored, Tuomas Rasimus from Finland and I co-edited a Festschrift of nearly 800 pages that we presented to him on his birthday in 2013. John was the friend whose cigarette smoke outside a hotel somewhere or outside his home I always enjoyed. But I never knew until his final days what a remarkably well-rounded person he had been in several different dimensions: in High School he ran the mile in 4 minutes 27 seconds; in College he swam for the Dartmouth Swimming team butterfly Relays and Individual Medleys; his wonderful baritone nurtured under Robert Shaw and known to so many in Nebraska-I never heard. I also had no idea that before Windows and the emergence of Search engines, he had developed his own "Quick Coordinance Generator" to search Coptic phrases in context; that he had spent six months as a car salesman headed for insurance before he heard Paul Tillich's lectures that turned him around and led him, after Army service and a stint at Union Theological Seminary, to leave New Testament Studies and become a professor of Religion.

John Turner changed the face of late Antique Studies, breaking down earlier boundaries and opening up new vistas for younger scholars. He will be sorely missed by many, especially his wife, Elizabeth Sterns; daughter Angela Turner; stepdaughter Sarah Elizabeth Sterns; brother Warren H. Turner; and many in-laws, nieces, nephews, and friends.

\author{
Kevin Corrigan \\ Emory University \\ kcorrig@emory.edu
}

